\title{
TEKTUALITAS SEJARAH DALAM MATI BAIK-BAIK, KAWAN
}

\section{TEXTUALITY OF HISTORY IN MATI BAIK-BAIK, KAWAN}

\author{
Yeni Yulianti \\ Balai Bahasa Kalimantan Barat \\ yendes.ugm@gmail.com
}

\begin{abstract}
ABSTRAK
Penelitian ini mengkaji tragedi 1965 dalam kumpulan cerpen Mati Baik-Baik, Kawan $(M B B K)$ karya Martin Aleida, dengan menggunakan pendekatan New Historicism. Pendekatan New Historicism memungkinkan untuk menjawab pertanyaan tentang tekstualitas sejarah dalam MBBK. New Historicism berpandangan bahwa karya sastra tidak dapat dilepaskan dari praksis-praksis sosial, ekonomi, dan politik karena ia ikut ambil bagian di dalamnya. Asumsi dasar yang dibangun dari teori ini adalah: 1) bahwa setiap tindakan ekspresif terkait erat dengan jaringan praksis budaya yang bersifat material; 2) bahwa teksteks sastra dan teks-teks nonsastra beredar tidak terpisahkan; 3) tidak ada teks diskursif apapun, baik yang fiksi maupun faktual, yang dapat menghadirkan secara utuh kebenaran dan hakikat kemanusiaan yang tak berubah. Metode yang digunakan adalah pembacaan pararel (parrarel reading) antara teks-teks sastra dan teks-teks nonsastra. Mengkaji tekstualitas sejarah dalam penelitian ini adalah mengkaji teks-teks dalam MBBK dalam menghadirkan kembali sejarah Tragedi 1965. Hasil penelitian tekstualitas sejarah Tragedi 1965 yang ditampilkan dalam $M B B K$ menekankan pada akibat dan dampak sesudah G30S berupa terjadinya pelbagai pelanggaran HAM terhadap korban.
\end{abstract}

Kata kunci: Mati Baik-Baik, Kawan, MBBK, Tragedi 1965, New Historicism

\begin{abstract}
This research reviews the 1965 Tragedy in the collection of short stories Mati Baik-Baik, Kawan (MBBK) by Martin Aleida using New Historicism perspective. The New Historism allows us to answer questions of textuality of history in MBBK. New Historicism has been applied as a theoretical framework asserting that literary pieces cannot be separated from political, social, and economic praxis. The theory is based on three basic assumptions: 1) that every expressive act is embedded in a network of material practices; 2) literary and nonliterary texts circulate inseparably; 3) no discourse, imaginative or archival, gives acces to unchanging truths nor expresses inalterable human nature. The research applied parrarel reading method involving literary and nonliterary texts. Any efforts to analyze the textuality of history in the research is to assess the texts in the collection of short stories MBBK through exposure of the 1965 Tragedy. The finding of research of textuality of history of the 1965 tragedy in MBBK put stress upon post impact of G30S such as human right abuse against victims.
\end{abstract}

Keywords: Mati Baik-Baik, Kawan; MBBK; 1965 Tragedy; New Historicism 


\section{PENDAHULUAN}

Dalam kehidupan berbudaya yang terikat ruang dan waktu, sastra sejatinya tidak dapat mengelak dari kondisi masyarakat dan situasi kebudayaan tempat karya sastra tersebut dihasilkan. Dalam kondisi ini, sastra sebagai hasil kreativitas pengarang tidak lagi sekedar sebagai cermin yang transparan dan pasif merefleksikan budaya dan masyarakatnya. Karya sastra bahkan dapat (turut) berpartisipasi dan menawarkan suatu nilai-nilai dalam batas-batas budaya, bahkan dalam kondisi tertentu ikut membangun dan memelihara batas-batas budaya tersebut bagi pembacanya (Greenblatt, 2005: 14). Dengan kata lain, sastrasebagaimana pandangan Faruk (2012) — dapat bertindak sebagai produk sekaligus produsen kebudayaan. Sastra tidak pula dapat dilihat hanya sebatas dari dalam dirinya saja (sebagai wilayah otonom). Sastra dapat dilihat pada batasan yang menghubungkannya dengan praksis-praksis sosial, ekonomi, dan politik yang ada di luar dirinya, karena semua teks, baik sastra maupun nonsastra, merupakan produk dari zaman yang sama dengan pelbagai pertarungan kuasa dan ideologi (Budianta, 2006).

Bertolak dari beberapa pandangan ini, karya sastra yang menampilkan masa lampau untuk menanggapi problematika masa kini mendapat tempat yang layak, terlebih terhadap karya sastra pada masa pasca Orde Baru yang bertemakan Tragedi 1965 yang menyuarakan kepedihan korban. Kita ketahui bersama bahhwa tragedi 1965 merupakan sejarah kelam yang dialami bangsa Indonesia. Dalam peristiwa tersebut terjadi pembantaian besar-besaran terhadap anak bangsa sendiri akibat konflik sosial politik kala itu. Diawali pada 1 Oktober 1965, rakyat Indonesia dikejutkan dengan peristiwa penculikan dan pembunuhan sejumlah jenderal Angkatan Darat. Peristiwa yang dikenal G30S ini menyulut perubahan peta politik di negeri ini dengan hancurnya Partai Komunis Indonesia (PKI). Tak lama kemudian, melalui Sidang Umum MPRS tahun 1966, PKI resmi dibubarkan.

Pergolakan politik di tingkat elit meluas ke akar rumput dengan terjadinya pembantaian besar-besaran oleh Angkatan Darat dan milisi serta massa yang berafiliasi dengannya terhadap orang-orang yang dituduh bergabung dan terlibat dengan PKI, khususnya di Jawa Tengah, Jawa Timur, dan Bali (Roosa, 2008:5). Tak kurang sekitar setengah juta orang terbunuh dalam tragedi tersebut (Cribb, 2012). Satu setengah juta orang ditangkap (Roosa, 2008:5) dan sekitar lebih dari sepuluh ribu orang diasingkan dan dikerjapaksakan di Pulau Buru. Pembantaian besar-besaran tersebut juga merupakan puncak akumulasi ketegangan dan konflik antara massa anti-PKI dan pro-PKI yang bergejolak sejak beberapa tahun sebelumnya, hingga menciptakan situasi "mereka atau kami". Tak ayal, pembantaian massal ini menjadi salah satu tragedi kemanusiaan terburuk dalam sejarah dunia Abad XX.

Tragedi yang dialami sebuah bangsa lazimnya menyimpan banyak cerita (sejarah) bahkan mitos. Dapat kita lihat dalam tragedi holocaust yang menimpa bangsa Yahudi Eropa yang menghasilkan banyak sekali memoar sejarah dan karya seni, baik sastra maupun film. Eksplorasi cerita sangat beragam, mulai (yang paling banyak) dari sudut pandang para korban hingga penggambaran sang fuehrer, Adolf Hitler. Di sisi lain, Tragedi 1965 yang dialami bangsa Indonesia 
(ironisnya) tidak banyak dijadikan inspirasi oleh para seniman, termasuk sastrawan (dalam melahirkan karya), khususnya di zaman Orde Baru.

Sangat sedikitnya karya sastra yang bertemakan Tragedi 1965 sudah dirasa beberapa tahun pascatragedi tersebut. Pada akhir tahun 1960-an, majalah sastra Horison pernah mengadakan sebuah diskusi sastra membicarakan karya-karya yang dimuat di majalah tersebut di Balai Budaya, Jakarta. Fuad Hassan sebagai salah satu pembicara melontarkan sinyalemen menarik. Menurutnya, karya sastra yang dimuat dalam majalah Horison pada tahun-tahun tersebut berwarna ungu. Yang dimaksudkan adalah bahwa karya sastra yang dimuat kebanyakan membicarakan perasaan-perasaan personal saja. Tema-tema sosial kurang muncul. Padahal baru saja terjadi kegoncangan sosial politik yang dahsyat di Indonesia yang mengakibatkan terbunuhnya ratusan ribu orang yang dianggap PKI (Budiman, 2006:168).

Dalam rentang kekuasaan Orde Baru selama 32 tahun, tercatat hanya beberapa karya sastra menonjol yang mengambil latar belakang Tragedi 1965 dan kekerasan yang menimpa para korban, antara lain novel Pergolakan (1974) karya Wildan Yatim, novelet Sri Sumarah dan Bawuk (1975) karya Umar Kayam, dan Trilogi Ronggeng Dukuh Paruk (1982, 1985, dan 1986) karya Ahmad Tohari.

Selain dalam bidang sastra, Tragedi 1965 juga pernah dimunculkan dalam bidang film melalui film propagandis terkenal berjudul Pengkhianatan $G 30$ S/PKI (1984). Film karya Arifin C. Noer ini merupakan versi resmi pemerintah Orde Baru tentang peristiwa G30S yang didalangi PKI. Film ini menjadi fenomenal di masa Orde Baru karena oleh pemerintah selalu diputar di TVRI setiap tanggal 30 September malam sejak dibuatnya. Ketika banyak TV swasta muncul, instruksi pemutaran tetap dilakukan dan berhenti semenjak tumbangnya rezim Orde Baru pada tahun 1998.

Selama zaman Orde Baru, pemerintah sangat ketat dalam mengontrol dan mengawasi sepak terjang warga negaranya sehingga membuat kebebasan berekspresi terbungkam. Lembaga seperti Komando Pemulihan Keamanan dan Ketertiban (Kopkamtib) yang dibentuk pemerintah amat ditakuti. Lembaga ini punya wewenang luar biasa untuk mengawal kepentingan pemerintah dengan melakukan apa saja, mulai dari pelarangan kegiatan tertentu, penangkapan orang, penahanan tanpa surat perintah, pengabaian atas pengadilan dan lain-lain (Haryanto, 1999:37). Para seniman dan sastrawan yang dituduh terlibat dalam Lembaga Kebudayaan Rakyat (Lekra) ditangkap dan ditahan, sebagian dibuang ke Pulau Buru. Karya-karya mereka dilarang beredar, termasuk karya-karya terkenal Pramoedya Ananta Toer yang dihasilkan selama penahanan di Pulau Buru. Pemerintah - secara terus menerus - menciptakan suasana yang sangat antiPKI melalui pelbagai cara. Hal ini yang menjadikan para sastrawan Indonesia sangat sedikit membuat karya yang berani mengeksplorasi tragedi bangsa ini secara jujur dan bebas.

Sebuah studi sastra kemudian menyatakan bahwa sastra Indonesia pada zaman tersebut terbagi menjadi dua bentuk, yang pertama adalah bentuk kesusasteraan yang hegemonik atau disebut sebagai kesusasteraan yang "diresmikan/diabsahkan", yang kedua adalah kesusasteraan sub-ordinat yang 
dibedakan menjadi tiga macam, yaitu kesusasteraan yang "dilarang", "yang diremehkan", dan "yang dipisahkan" (Heryanto via Faruk, 1999:98-99).

Memasuki tahun 1998, konstelasi politik di Indonesia berubah total. Rezim Orde Baru di bawah Presiden Soeharto tumbang oleh gelombang demonstrasi mahasiswa. Era Reformasi pun dimulai dengan perubahan yang terjadi di pelbagai bidang. Kebebasan berekspresi dan berpendapat mulai mendapat tempat yang layak. Hal-hal yang tabu dibicarakan selama Orde Baru seperti kontroversi sejarah Tragedi 1965 menjadi lebih bebas dibicarakan. Sejarah (tunggal) Tragedi 1965 yang sebelumnya didesakkan Orde Baru pun pelan-pelan mulai mendapat tantangan dari versi-versi yang berbeda bahkan berseberangan.

Dalam era Reformasi ditandai juga dengan menghangatnya pembicaraan tentang Tragedi 1965 yang oleh sebagian besar masyarakat Indonesia dianggap masih misterius dan samar-samar. Salah satu tonggak menghangatnya isu tentang Tragedi 1965 adalah dalam masa kepresidenan Abdurrahman Wahid atau Gus Dur. Pada tahun 2000, Gus Dur menyampaikan permintaan maaf kepada para korban dan keluarganya atas terjadinya Tragedi 1965. Bahkan Gus Dur kemudian menyampaikan usulan kontroversial yaitu mencabut TAP MPRS No. XXV/MPRS/1966 yang berisi ketetapan tentang pembubaran PKI, dan pernyataan sebagai organisasi terlarang di seluruh wilayah Republik Indonesia, dan larangan kegiatan untuk menyebarkan faham atau ajaran Komunisme/MarxismeLeninisme. Usulan Gus Dur ini menjadi polemik di masyarakat, hingga akhirnya MPR memutuskan menolak usulan tersebut. Isu dan wacana tentang Tragedi 1965 terus bergulir hingga masa pemerintahan Susilo Bambang Yudhoyono. Di masyarakat, isu ini juga berkembang, khususnya di kalangan korban serta keluarganya dan di lembaga-lembaga sosial-kemanusiaan sebagai lembaga pembela korban.

Di dunia sastra mengalami gejala serupa. Karya-karya sastra yang semula diharamkan oleh pemerintah Orde Baru mulai banyak bermunculan di toko-toko buku, termasuk novel-novel Pramoedya Ananta Toer yang kemudian menjadi primadona. Para pengarang, baik dari kalangan eks tapol maupun yang bukan, mulai gencar mengeluarkan karya-karyanya baik berupa novel, cerpen, dan puisi dengan mengeksplorasi tema tentang Tragedi 1965.

Salah satu karya yang bertemakan Tragedi 1965 adalah kumpulan cerpen Mati Baik-Baik, Kawan (MBBK) karya Martin Aleida (2009). Kumpulan cerpen ini berisi delapan cerpen dan satu memoar pribadinya ketika bebas dari tahanan dan kemudian bekerja di majalah Tempo. Delapan cerpen tersebut adalah Mangku Mencari Doa di Daratan Jauh, Tanpa pelayat dan Mawar Duka, Malam Kelabu, Leontin Dewangga, Ode untuk Selembar KTP, Bertungkus Lumus, Dendang Perempuan Pendendam, dan Salawat untuk Pendakwah Kami. Sedangkan memoarnya berjudul Ratusan Mata di Mana-Mana.

Martin Aleida merupakan sastrawan yang lahir pada 31 Desember 1943, di Tanjung Balai, Sumatera Utara. Tahun 1963 ia mulai menetap di Jakarta dan menjadi aktivis Lekra Jakarta Raya. Setelah meletusnya G30S 1965 ia ikut ditangkap dan ditahan selama kurang lebih setahun. Selama zaman Orde Baru, Aleida - seperti para sastrawan eks tapol lainnya - umumnya tidak diberi ruang berekspresi alias dibungkam. Jangankan bebas berkarya, untuk hidup sehari-hari 
saja sangat sulit karena ketatnya diskriminasi yang ditetapkan negara. Namun setelah era Reformasi, kebebasan berekspresi tidak lagi dikekang. Para sastrawan eks tapol, termasuk Aleida mendapatkan euforia untuk dapat kembali bebas berkarya.

Adanya keterkaitan antara apa yang terjadi dalam bidang sosial dan politik dengan kesusasteraan pasca Orde Baru, khususnya menyangkut isu Tragedi 1965 mengindikasikan bahwa memang sejatinya sastra-menurut pandangan New Historicism $(\mathrm{NH})$ - tidak lagi dianggap bersifat "ahistoris", yang hanya beroperasi dalam wilayah estetik yang otonom dan dipisahkan dari aspek-aspek yang berada "di luar" sastra. Sastra dianggap berada dalam pusaran budaya dan ikut membangun, mengartikulasikan, dan mereproduksi konvensi, norma, dan nilainilai budaya melalui tindak verbal dan imajinasi kreatifnya (Budianta, 2006:2-4).

Cerpen-cerpen yang terhimpun di dalam $M B B K$ termasuk dalam posisi yang serupa seperti pandangan $\mathrm{NH}$ di atas. Cerpen-cerpen yang ditulis semenjak tumbangnya Orde Baru (kecuali cerpen Malam Kelabu) ini bertemakan Tragedi 1965 dalam pengalaman korban. Keberadaannya amat dipengaruhi dan (dianggap) ikut mempengaruhi kondisi sosial politik di Indonesia pasca Orde Baru. Isu dan tema yang diangkatnya menjadikan cerpen-cerpennya amat tipikal, bahkan menurut penilaian beberapa kawannya dianggap terlalu realis dan sesak dengan jurnalisme (Aleida, 2003:xvii).

Pengarang kumcer $M B B K$ yang menjadi saksi dan mengalami langsung peristiwa sejarah kelam bangsa pada masa itu memberikan fakta-fakta dari sisi tersembunyi dalam karya fiksinya. Ia mengkorelasikan sisi kepengarangannya dengan pengalamannya tersebut dengan apa yang ia sebut: "sastra kesaksian". Sastra adalah dimensi tertinggi dari kesaksian tentang hidup-pengalaman fisik maupun batin. Tak ada yang menyerukan namanya untuk tampil memberikan kesaksian. Yang didengarnya hanyalah panggilan dari dalam (hati). Seruan untuk mencari keadilan. Menyambut panggilan untuk berbagi rasa (Aleida, 2003:x).

Dengan mengeksplorasi tragedi sejarah bangsa yang kelam melalui sastra, Aleida tampak menempatkan sastra dan sejarah dalam posisi yang sejajar. Ketika sastra dan sejarah dibicarakan secara bersama-sama, segera muncul pertanyaan, apakah ada fiksi di dalam sejarah dan apakah ada fakta di dalam sastra? Secara umum, sastra selalu dikaitkan dengan fiksi, sedangkan sejarah tidak dapat dipisahkan dari fakta masa lalu. Batasan ketat Inilah yang selama ini dipahami ketika membicarakan sastra yang bersifat fiksi. Akan tetapi, menurut Purwanto (2001:29), dalam wacana dekonstruktif antara sastra dan sejarah, kategori tersebut menjadi lain. Sebagai sebuah realitas, sejarah dan sastra sering dianggap berada dalam tataran yang sama. Fiksi dan fakta tidak dapat begitu saja secara kaku diasosiasikan hanya dengan satu di antara keduanya, yaitu hanya berkaitan dengan sastra atau hanya dengan sejarah.

Sejarah dan sastra sesungguhnya bergulat dalam satu bidang yang sama yaitu bahasa. Sejarah sebagai kenyataan hanya merupakan sesuatu yang terjadi satu kali pada masa lalu dan tidak terulang, sedangkan sejarah sebagai sebuah rekonstruksi tertulis dan lisan yang kita kenal saat ini adalah produk dari bahasa, wacana, dan pengalaman sesuai dengan konteksnya. Hal ini berarti sebagai sebuah realitas, sejarah hanya ada pada masa lalu dan tidak mungkin dijangkau 
oleh sejarawan. Rekonstruksi sejarah adalah produk subjektif dari sebuah proses pemahaman intelektual yang dilambangkan dalam simbol-simbol kebahasaan atau naratif dan dapat berubah dari waktu ke waktu, dari satu tempat ke tempat lain, atau dari satu orang ke orang lain. Sementara itu, pada saat yang sama, sastra berhasil menampilkan citra dirinya sejajar sebagai sejarah karena mampu menghadirkan situasi faktual dari masa lalu sebagai sebuah narasi melalui imajinasi kebahasaannya. Hal itu berarti bahwa kebenaran sejarah maupun sastra adalah kebenaran relatif (Purwanto, 2001:29-30).

Teks-teks sastra dalam kumpulan cerpen (kumcer) $M B B K$ dan teks-teks sastra lain yang bermuatan sejenis beserta teks-teks nonsastra yang melingkupinya berusaha menghadirkan kembali sejarah Tragedi 1965 yang kelam pada masa pasca Orde Baru. Di dalam proses ini terjadi "pergulatan" dan "pertengkaran"yang dalam bahasa Greenblatt-disebut kendala (constrain) dan mobilitas (mobility) dalam menyikapi sejarah Tragedi 1965, baik dalam hubungannya dengan pengungkapan dan penghadiran kembali ingatan sejarah, penyikapan terhadap korban, dan keinginan menuju proses rekonsiliasi.

Penelitian ini menggunakan pendekatan New Historicism $(\mathrm{NH}) . \mathrm{NH}$ merupakan teori sastra yang mulai mengemuka di Amerika Serikat pada tahun 1980-an yang menentang kajian tekstual-formalis dalam sastra yang diusung mazhab New Criticism. Teori ini dicetuskan oleh Stephen Greenblatt, profesor sastra dari University of California, Berkeley, dan kemudian didukung oleh kritikus sastra lain semacam Louis A. Montrose dan Catherine Gallagher.

Teori NH mengusung misi ingin mengembalikan dimensi kesejarahan dalam studi kesusasteraan, yaitu melengkapi praktik sastra Formalis yang berlaku, dengan memperluas perhatian pada konteks historis di mana teks-teks sastra berasal/dibuat (White, 1989: 293). NH menentang isolasi teks dari konteks kesejarahannya, dan ingin menguraikan kondisi sejarah dan budaya ketika teks tersebut diproduksi, bagaimana pemaknaannya, efek-efeknya, dan juga evalusi dan penafsiran kritis terhadapnya.

NH merepresentasikan upaya untuk menggambarkan ulang bidang sosial budaya di mana karya sastra dan drama pada awalnya diproduksi, dan untuk menempatkan karya-karya tersebut, tidak hanya dalam hubungan dengan genre dan model wacana lain, tetapi juga dalam hubungan dengan lembaga-lembaga sosial dan praktik-praktik non-diskursif yang sezaman (Montrose, 1989:17). NH merupakan fenomena baru dalam studi kesusasteraan dengan memberi kesempatan pada para kritikus sastra untuk menyeberangi batas-batas yang memisahkan antara sejarah, antropologi, seni, politik, sastra, dan ekonomi (Veeser, 1989: ix).

NH mengambil posisi yang berbeda dengan pandangan-pandangan sastra sebelumnya, misalnya yang menganggap sejarah sosial dan intelektual hanya sekedar sebagai "latar belakang" suatu teks sastra, atau yang menganggap teks sastra sebagai "refleksi" atas karakteristik pandangan dunia (world view) dalam suatu era. NH memahami suatu teks sastra sebagai: "berada" (situated) di dalam lembaga, praktik sosial, dan wacana yang membentuk budaya keseluruhan dalam waktu dan tempat tertentu, di mana teks sastra berinteraksi, baik sebagai produk maupun produsen dari pelbagai energi dan kode budaya (Abrams, 1999: 183). NH 
berpandangan bahwa dalam analisis budaya, karya sastra kanon diposisikan sama dengan karya sastra minor atau yang picisan, bahkan dengan teks yang dianggap nonsastra (Gallagher, 2000:10). Tidak ada hierarki dalam hal ini, karena setiap teks budaya (karya sastra kanon, minor, dan nonsastra) turut menyumbang kodekode, energi-energi, dan nilai-nilai budaya pada zamannya.

Istilah NH pertama kali digagas oleh Greenblatt pada tahun 1982 dalam pengantarnya untuk sebuah kumpulan tulisan tentang sastra era Renaissance berjudul The Forms of Power and the Power of Forms in The Renaissance, yang dimuat dalam jurnal Genre. Dalam pengantar ini disebutkan bahwa di dalam karya sastra (Renaissance) terdapat jalinan pertemuan (intersection) antara sastra dan sejarah. Karya sastra tidak lagi dianggap sebagai seperangkat tetap teks-teks yang terpisah dari semua bentuk ekspresi lain atau sebagai seperangkat refleksi dari fakta sejarah yang terletak di luar mereka. Anggapan yang mengatakan bahwa terdapat pemisahan yang ketat antara "sastra sebagai latar depan" dan "politik sebagai latar belakang" atau dalam bentuk yang umum, antara produksi artistik (termasuk sastra) dengan pelbagai macam produksi sosial lainnya harus ditentang. Ditegaskan pula bahwa karya fiksi mempunyai posisi dan derajat yang sama dengan unsur-unsur kebudayaan lain dalam membentuk dan mengembangkan suatu kebudayaan pada waktu, tempat, dan konteks tertentu. Karya sastra pada khususnya, dan kesenian pada umumnya, tidak berdiri sendiri. Keberadaannya melekat dan tidak dapat dipisahkan dari pelbagai sektor budaya lainnya, seperti sosial, ekonomi, dan politik masyarakatnya. Pengarang, melalui karya sastranya, turut andil memberikan sumbangan ide, gagasan, dan nilai-nilai bagi pengembangan kebudayaan pada umumnya (Greenblatt, 1982 via 2005: 2).

NH hadir lebih sebagai seperangkat karakteristik dan praktik dari pada sebuah mazhab atau metode (Greenblatt, 2005: 3), atau bahwa metode NH bersifat elastis bahkan cair (Greenblatt, 2005: 6). Meski demikian terdapat fondasi pokok yang menjadi titik tolak metode $\mathrm{NH}$ sebagai berikut.

"Social actions are themselves always embedded in systems of public signification, always grasped, even by their makers, in acts of interpretation. ...

Language, like other sign systems, is a collective construction; our interpretive task must be to grasp more sensitively the consequences of this fact by investigating both the social presence to the world of the literary text and the social presence of the world in the literary text." (Greenblatt, 1980:5)

Dalam pernyataannya di atas, Greenblatt mengatakan bahwa sejatinya bahasa (termasuk sastra) merupakan bagian dari struktur simbolik yang ada dalam masyarakat. Konstruksi simbolisnya dapat digali dan dianalisis dengan menyelidiki dua sisi yang dialektis, yaitu kehadiran sosial ke dalam dunia karya sastra dan kehadiran sosial dalam karya sastra. Greenblatt (2005:12) menambahkan, bahwa dalam merekonstruksi sejarah suatu kebudayaan tertentu dapat dilakukan dengan merekonstruksi batas-batas yang mendasari keberadaan suatu karya sastra.

Montrose (1989:10) mengukuhkan pendapat Greenblatt di atas dengan menyatakan garis besar metode $\mathrm{NH}$ yaitu dengan menaruh perhatian pada hubungan timbal balik antara historisitas teks dan tekstualitas sejarah. 


\section{METODE}

Telah disampaikan di atas bahwa penelitian ini menggunakan pendekatan $\mathrm{NH}$, bahwa metode pembacaan pararel (parrarel reading) antara teks-teks sastra dan teks-teks nonsastra yang dipakai dalam kajian ini, biasanya dalam sebuah periode historis yang sama. NH menolak privilise teks sastra (otonomi teks). NH memandang bahwa teks-teks sastra dan teks-teks nonsastra diberi bobot yang sama dan terus menginformasikan dan menginterogasikan satu sama lain (Barry, 2002:116).

\section{PEMBAHASAN \\ Tekstualitas Sejarah}

Konsep tekstualitas sejarah dalam pandangan Montrose (1989:10) menyaran pada, pertama, bahwa pada hakikatnya kita tidak dapat mengakses masa lalu secara penuh dan otentik tanpa dimediasi oleh jejak-jejak teks yang masih hidup di masyarakat yang bersangkutan. Jejak-jejak tersebut tidak dapat kita asumsikan sebagai sebuah kesatuan melainkan menjadi-setidaknya - sebagai akibat pada proses sosial yang kompleks dan pelik dari pelestarian dan penghapusan; Kedua, bahwa jejak tekstual itu sendiri tunduk pada mediasi tekstual berikutnya ketika mereka ditafsirkan sebagai "dokumen" yang di atasnya sejarawan mendasarkan teks mereka sendiri yang kemudian disebut 'sejarah". Bentuk-bentuk naratif dan retorika yang terdapat dalam tekstualitas sejarah hampir selalu tidak akan lengkap dalam menjelaskan dan mengakses "sejarah".

Konsep tekstualitas sejarah yang diusung Montrose berbanding lurus dengan pendapat yang menyatakan bahwa sejarah sebagai kenyataan hanya merupakan sesuatu yang terjadi satu kali pada masa lalu dan tidak terulang, sedangkan sejarah sebagai sebuah rekonstruksi tertulis dan lisan yang kita kenal saat ini adalah produk dari bahasa, wacana, dan pengalaman sesuai dengan konteksnya. Hal ini berarti sebagai sebuah realitas, sejarah hanya ada pada masa lalu dan tidak mungkin dijangkau oleh sejarawan. Rekonstruksi sejarah adalah produk subjektif dari sebuah proses pemahaman intelektual yang dilambangkan dalam simbol-simbol kebahasaan atau naratif dan dapat berubah dari waktu ke waktu, dari satu tempat ke tempat lain, atau dari satu orang ke orang lain. Sementara itu, pada saat yang sama, sastra berhasil menampilkan citra dirinya sejajar sebagai sejarah karena mampu menghadirkan situasi faktual dari masa lalu sebagai sebuah narasi melalui imajinasi kebahasaannya. Hal itu berarti bahwa kebenaran sejarah maupun sastra adalah kebenaran relatif (Purwanto, 2001:30).

Pada tataran praktis, hubungan antara fakta dan fiksi tidak ada perbedaan yang berarti secara tekstual karena sastra dan sejarah bergulat dalam bidang yang sama, yaitu bahasa. (Tekstualitas) sejarah yang ada dalam karya sastra-dengan demikian - termasuk dengan sejarah dalam tataran pengetahuan yang tergantung pada wacana dan bentuk representasi antarteks pada konteks sosial dan institusional yang lebih luas di dalam atau melalui bahasa karena realitas objektif masa lalu-bagaimanapun - telah berjarak. (Tekstualitas) sejarah dalam karya sastra sejajar dengan sejarah sebagai ilmu yang tidak dapat berperan sebagai representasi tunggal atas objektivitas masa lalu karena jarak telah mereduksi kemampuan rekonstruksinya. 
Sejarah atau dunia yang diacu dalam karya sastra juga bukan sekedar latar belakang yang dengan transparan dapat diakses. Sejarah terdiri dari pelbagai teks yang masing-masing menyusun satu versi tentang kenyataan sejarah. Dalam pandangan ini, "kenyataan sejarah" tidak lagi tunggal dan absolut, tetapi terdiri dari pelbagai macam versi yang penuh kontradiksi, keterputusan, pluralitas, dan keragaman. Kaitan antara karya sastra dan "sejarah" adalah kaitan intertekstual antara pelbagai teks (fiksi maupun faktual) yang diproduksi pada kurun waktu yang sama atau berbeda (Budianta, 2006:4).

Kajian tekstualitas sejarah mengarah pada bagaimana teks-teks dalam MBBK ini berperan menghadirkan kembali sejarah Tragedi 1965 dari pengalaman korban. "Penghadiran kembali" dalam konteks ini adalah upaya membaca sejarah dari "bawah", dari pengalaman para korban yang terpinggirkan, sebagai alternatif dari pembacaan sejarah dari "atas", yang selama ini didesakkan pemerintah Orde Baru, yang pengaruhnya masih bertahan di zaman Reformasi.

Pembahasan ini pada dasarnya adalah refleksi atas kode-kode perilaku yang berlaku semasa era Reformasi di mana kebebasan berekspresi bagi mantan tapol lebih terjamin. Keinginan pengarang MBBK untuk berkarya adalah semata-mata untuk menuntaskan "dendam"nya dengan cara "mengatakan yang baik-baik" atau bersaksi melalui karya sastra tentang tragedi bangsa yang kelam pasca 1965 . Aspek penghadiran sejarah Tragedi 1965 dalam hal ini meliputi beberapa "kesaksian" yang dihadirkan pengarang yaitu pelanggaran HAM berupa kejahatan kemanusiaan yang dialami para tokoh yang menjadi korban, ekspresi dendam dari para korban, dan ironi kemanusiaan yang dimunculkan dalam MBBK (Aleida, 2003:xv-Xvi).

Cerpen-cerpen dalam MBBK menghadirkan pengalaman korban yang berasal dari rakyat biasa. Ada petani miskin (dalam Mangku Mencari Doa di Daratan Jauh, Malam Kelabu, Dendang Perempuan Pendendam), ada seorang guru bahasa Inggris (dalam Bertungkus Lumus), ibu rumah tangga (dalam Ode untuk Selembar KTP), para penggali kubur (dalam Tanpa Pelayat dan Mawar Duka), penjual warung makan (Leontin Dewangga), dan penjual kopiah (dalam Salawat untuk Pendakwah Kami). Figur dari korban yang berasal dari rakyat biasa dengan pelbagai profesi di atas merupakan representasi suara-suara marjinal yang selama ini cenderung diabaikan oleh Sejarah (dengan S).

\section{Pelanggaran HAM Berat yang Dialami Korban}

Konstruksi sejarah Tragedi 1965 dihadirkan kembali melalui kumcer MBBK dalam bentuk eksplorasi pelanggaran HAM berat dan diskriminasi yang dialami para tokoh dalam cerpen dan keluarganya. Pelanggaran HAM dalam konteks ini didasarkan pada UU No. 39 tahun 1999 tentang Hak Asasi Manusia dan UU No 26. Tahun 2000 tentang Pengadilan HAM, pasal 9 yang menyatakan bahwa pelanggaran HAM berat berupa kejahatan kemanusiaan yang meliputi:

a. pembunuhan;

b. pemusnahan;

c. perbudakan;

d. pengusiran atau pemindahan penduduk secara paksa; 
e. perampasan kemerdekaan atau perampasan kebebasan fisik lain secara sewenang-wenang yang melanggar (asas-asas) ketentuan pokok hukum internasional;

f. penyiksaan;

g. perkosaan, perbudakan seksual, pelacuran secara paksa, pemaksaan kehamilan, pemandulan atau sterilisasi secara paksa atau bentuk-bentuk kekerasan seksual lain yang setara;

h. penganiayaan terhadap suatu kelompok tertentu atau perkumpulan yang didasari persamaan paham politik, ras, kebangsaan, etnis, budaya, agama, jenis kelamin atau alasan lain yang telah diakui secara universal sebagai hal yang dilarang menurut hukum internasional;

i. penghilangan orang secara paksa; dan

j. apartheid.

Pelanggaran HAM berupa diskriminasi mengacu pada UU No. 39 tahun 1999 tentang Hak Asasi Manusia yang menyatakan bahwa diskriminasi adalah setiap pembatasan, pelecehan, atau pengucilan yang langsung ataupun tak langsung didasarkan pada pembedaan manusia atas dasar agama, suku, ras, etnik, kelompok, golongan, status sosial, status ekomomi, jenis kelamin, bahasa, keyakinan politik. yang berakibat pengurangan, penyimpangan atau penghapusan pengakuan, pelaksanaan atau penggunaan hak asasi manusia dan kebebasan dasar dalam kehidupan baik individual maupun kolektif dalam bidang politik, ekonomi, hukum, sosial, budaya. dan aspek kehidupan lainnya.

Berikut uraian pelanggaran HAM yang dialami para tokoh dalam kumcer MBBK. 1. Pembunuhan

Kasus pelanggaran HAM berat berupa pembunuhan terdapat di hampir semua cerpen dalam MBBK. Peristiwa pembunuhan tersebut dialami oleh para tokoh yang terlibat PKI dan organisasi pendukungnya, Barisan Tani Indonesia (BTI).

Dalam cerpen Mangku Mencari Doa di Daratan Jauh peristiwa pembunuhan dialami oleh orang tua Mangku, seorang petani miskin di Bali yang menerima tanah cuma-cuma dari BTI. Orang tua Mangku dibunuh oleh tuan tanah pada waktu terjadi huru-hara politik 1965 di Bali. Lihatlah kutipan berikut.

"Orang tua itu dibunuh karena menerima tanah cuma-cuma dari organisasi tani yang dituduh merampas tanah tuantanah dan membagi-bagikannya kepada petani tak bertanah seperti dia. Huru-hara politik pun menggelegar. Bali berdarah. Hukum rimba direbut orang-orang yang dirasuki roh Leak. Tuantanah, yang menjadi korban landreform, melihat matahari baru menyingsing untuk merebut kembali tanah mereka" (Aleida, 2009: 9).

Bersama petani-petani lainnya, orang tua Mangku dibunuh dengan bengis. Mangku yang masih kecil, terselamatkan karena isak tangisnya yang membuat luluh para algojo dan sang tuantanah. Mangku dibiarkan hidup dan kemudian bekerja sebagai pembantu di rumah tuantanah. Simaklah kutipan berikut.

"Begitulah, suatu pagi, ayah Mangku diseret ke tepi lubang, tengkuknya dihantam linggis, dan bersama jasad petani senasib, dia ditimbuni, tanpa doa, konon pula airmata. Di tempat lain, dalam huru hara paling bengis itu, anak-anak menyertai ayah mereka ke dalam lubang. Mangku mujur. Air mata kanak-kanaknya jadi juru selamat. Pemilik tanah membiarkannya menempati gubuk orang tuanya. Dia jadi pembantu di rumah tuantanah itu" (Aleida, 2009: 9-10). 
Peristiwa pembunuhan lain ditampilkan dalam cerpen ini ketika Mangku sampai di Pemalang, Jawa Tengah dalam perjalanannya ke Lampung. Di sebuah pantai yang bernama Widuri, ia menjumpai sebuah kru film asing yang sedang mendokumentasikan kuburan massal di tepi pantai tersebut, yang diduga kuburan sejumlah orang terdiri dari guru, lurah, dan pamong lain yang dituduh komunis. Dalam pembuatan film itu, sejumlah saksi juga diwawancarai. Menyaksikan kejadian tersebut, perasaan Mangku bergejolak, merinding teringat nasib ayahnya. Perhatikan kutipan berikut.

"Di Pemalang, dekat pantai Widuri, dia merinding, juga tersenyum kecut. Ceritanya, ketika dia akan menggelar pertunjukan, adalah kru film Austria yang sedang mengambil gambar di semak-semak, tak jauh dari bibir pantai. Diyakini, di situ dikuburkan sejumlah guru, lurah, dan pamong lain yang dituduh komunis. Mangku tergoda bergabung dengan kerumunan manusia di semak-semak itu. Di depan kamera, seorang saksi mata menceritakan bahwa suatu malam, akhir Oktober 1965, ketika dia berusia 13, dia dengar rentetan tembakan dari arah laut. Esok paginya, dia pergi ke pantai menemui teman-temannya. Kaget, di situ dia jumpai sekelompok orang dewasa sedang menyeret-nyeret mayat yang tergeletak dingin di pantai. Anak-anak tanggung yang mengerubung disuruh ikut menyeret mayat yang sudah tak berdarah, dan melemparkannya ke lubang. Mangku merunduk, hatinya meraung. Tampil pula saksi lain. Orang ini, berusia di atas 60, mengaku disekap di Nusakambangan, sebelum dipencilkan ke Pulau Buru. "Mereka yang terbaring di sini," kata orang itu, "adalah orang-orang yang sangat disegani, dihormati. Mereka guru, pamong terbaik di daerah ini" (Aleida, 2009:14).

Dalam bagian ini, pengarang tampaknya ingin menjejalkan serangkaian fakta sejarah bahwa setelah dilakukan penelitian oleh lembaga korban di antaranya YPKP '65, memang telah ditemukan kuburan massal di daerah Pantai Widuri, Pemalang.

Peristiwa pembunuhan diangkat pula dalam cerpen Tanpa Pelayat dan Mawar Duka. Dalam cerpen yang terbit pertama kali di harian Kompas, 4 Februari 2007 ini menceritakan derita seorang yang dianggap pengkhianat dan pendurhaka oleh teman-temannya yang pada masa ajalnya yang hanya didampingi istrinya dengan tak seorang pun pelayat yang datang.

Tokoh $\mathrm{Ba}$ dalam cerpen ini digambarkan mengalami kecemasan dan ketakutan tatkala terjadi perubahan politik drastis dengan lengsernya sang pemimpin tiran yang lebih dari tiga puluh tahun memerintah. Dengan kondisi kesehatan yang sangat buruk akibat penyakit gula yang kronis, Ba merenungi dan membayangkan segala perbuatannya dulu yang dianggap mengkhianati tementemannya. Dia mencemaskan dendam yang kemungkinan dihadapi.

Ketika Ba meninggal dan hendak dikuburkan, tak seorang pun datang melayat termasuk orang-orang militer yang dulu menangguk keuntungan darinya. Hanya istrinya yang mengantarkan jenazah. Anak angkatnya semata wayang belum datang dari Australia, tempatnya bersekolah.

Kesunyian penguburan tersebut tak membuat para penggali kuburan bergerak menawarkan bantuan. Siapa sangka para penggali kubur tersebut memang sedang melampiaskan dendam kepada Ba yang terbujur kaku di peti matinya. Ba dianggap berdosa atas kelakuannya jaman dulu. Lihatlah kutipan berikut.

"Para penggali kubur yang tak kuasa menahan dendam, yang memandang peti mati dengan mata nanar dari gundukan tanah merah di balik pokok-pokok kemboja, adalah anak-anak dari petani tak bertanah, nan buta huruf, yang dengan sukacita menerima rezeki yang tak pernah 
mereka impikan. Tetapi, tanah itu jugalah yang membawa malapetaka menyusul pemusnahan "sampai ke akar-akarnya" terhadap mereka yang dituduh, tanpa bukti, membunuh para jenderal. Yang bernasib buruk dicampakkan ke dalam kuburan massal. Banyak yang darahnya memerahkan air sungai begitu kepala mereka yang terkulai, karena bacokan atau terjangan peluru, ditendang ke dalam air...Tahun yang menakutkan itu telah membakar hati para penggali kubur yang membangkang dan tetap berdiam diri di gundukan tanah merah itu. Mereka tahu, lelaki di peti mati itu telah banyak memakan korban di kalangan teman-temannya sendiri." (Aleida, 2009:22-23).

Para penggali kubur tersebut melampiaskan kesumatnya dengan sebentuk protes membiarkan jenazah Ba tidak terkuburkan. Mereka pedih teringat kelakuan Ba dahulu sehingga ayah-ayahnya mereka disiksa dan dibunuh.

"Di gundukan tanah merah itu semua cuma duduk mencangkung. Mematikan rokok. Diam. Pikiran mereka melayang mengenang ayah mereka yang dipaksa naik ke atas truk di tengah malam, dilarikan entah ke mana. Disiksa untuk mengakui apa yang tak pernah mereka perbuat, atau pikirkan sekalipun. Dalam sebuah buku dilaporkan, karena militer kewalahan harus memberi makan pesakitan yang begitu banyak pada waktu itu, lantas dikeluarkan perintah berdarah dingin: “Kirimkan mereka ke sekolah, ke sukabumi... ya, bunuh mereka!" (Aleida, 2009:23).

Peristiwa pembunuhan diangkat pula dalam cerpen Malam Kelabu. dalam cerpen yang dimuat pertama kali oleh majalah Horison pada Februari 1970 ini peristiwa pembunuhan dialami ayah Partini, yang bernama Mulyoharjo.

Mulyoharjo merupakan pengacara BTI yang gigih memperjuangkan para petani miskin yang menyerobot paksa tanah milik tuan tanah berdasarkan aturan landreform. Setelah meletus G30S, Mulyoharjo ditangkap dan kemudian dihabisi di Jembatan Bacam, Solo. Lihatlah kutipan berikut yang menggambarkan sosok Mulyoharjo dan kematian tragis yang dideritanya melalui penuturan Carik Laban.

"Dia orang terkenal. Bukan saja di desanya. Bukan saja di Laban ini. Dia dikenal di seluruh Kabupaten Sukoharjo, malah dikenal sampai ke kota Solo. Dia pimpinan Partai Komunis Indonesia. Di Solo dia dikenal sebagai pengacara, pembela Barisan Tani Indonesia dalam penyerobotan-penyerobotan tanah. Dia dicintai oleh orang-orang yang dia pimpin. Tapi, dia juga musuh bebuyutan dari rakyat banyak. Dia juga musuhku. Musuhku...Di pengadilan dia membela BTI yang menyerobot tanahku. Dia kalah sebelum hakim menjatuhkan vonis. Gerakan Tiga Puluh September meletus. Dia ikut hilang. Dia dihabisi di Bacam, dilemparkan ke bengawan seperti bangkai ayam" (Aleida, 2009:35).

Pembantaian terhadap orang-orang BTI yang dituduh PKI memang terjadi di wilayah Karisedenan Surakarta pada tahun 1965-1966. Surakarta merupakan basis kuat PKI ditandai dengan menangnya partai ini dalam pemilu 1955. Dukungan semakin meluas hingga tahun 1960-an di wilayah pedesaan maupun perkotaan ketika terjadi pelaksanaan program pembagian tanah untuk petani miskin yang ditunjukkan dalam kebijakan Undang-Undang Pokok Agraria (UUPA) dan Undang-Undang Pokok Bagi Hasil (UUPBH). Melalui dua undangundang tersebut, BTI sebagai underbouw PKI melakukan dorongan untuk memajukan kebijakan tersebut lebih cepat dengan aksi yang diinterpretasikan para lawan politik PKI sebagai "aksi sepihak" yang sewenang-wenang.

Aksi-aksi sepihak disikapi dengan berbeda oleh kekuatan-kekuatan politik di luar PKI. Ketegangan-ketegangan kecil di tingkat akar rumput sering muncul dengan pelbagai kualitas dan intensitasnya. Konfrontasi atas problem akses kepemilikan tanah mendorong polarisasi di antara kelas-kelas masyarakat yang ada. Polarisasi makin menguat tatkala intervensi kebijakan negara terhadap 
problem tanah mengalami kegagalan. Terjadi proses hadap-berhadapan masingmasing kelas sosial yang ada beserta kepentingan primordial yang ada (Narwaya, 2010:96).

Setelah meletusnya G30S, polarisasi kekuatan politik dan sosial di Surakarta berubah drastis. Melalui aksi militer yang anti PKI, dibantu kekuatan massa anti PKI dari golongan agama dan nasionalis, kekuatan PKI dihancurkan. Orang-orang yang dituduh PKI dikejar, ditangkap, dan dibantai. Menurut Narwaya (2010:102103), ada beberapa pola penangkapan dan pembunuhan massal yang terjadi di Surakarta. Pertama, penangkapan dan sekaligus pembunuhan massal dilakukan secara langsung oleh pihak tentara dan polisi. Kedua, penangkapan dan pembunuhan dengan melibatkan dan menggunakan massa partai dan ormas-ormas yang secara politik memiliki perbedaan dalam sikap dan ideologi. Ketiga, penangkapan dan pembunuhan dengan melalui kerja sama antara militer dan polisi dengan berbagai kelompok massa. Dan yang terakhir, yang juga menjadi pola yang sering muncul adalah pemanggilan secara resmi oleh para pejabat daerah/desa kepada mereka yang dianggap terlibat dan bersangkut paut dengan PKI.

Dalam cerpen Leontin Dewangga, peristiwa pembunuhan diangkat melalui narasi pengarang yang menggambarkan peristiwa G30S dan dampaknya bagi para anggota dan simpatisan PKI. Peristiwa G30S yang merupakan perseteruan politik angkatan darat dan golongan kiri menemukan jalan penyelesaiannya sendiri setelah sekelompok tentara menculik dan membunuh para jenderal. Kaum komunis dan kaum kiri lainnya dituduh berada di belakang peristiwa tersebut. Akibatnya, terjadilah pembantaian besar-besaran terhadap orang-orang yang dituduh terlibat PKI termasuk anak-anak dan wanita yang sedang mengandung terutama di desa dan kota-kota kecil (Aleida, 2009:52-53).

Peristiwa pembunuhan diangkat pula dalam cerpen Dendang Perempuan Pendendam. Cerpen ini mengisahkan dendam keluarga Las kepada Pakde Suto, orang yang menjadi biang keladi tertangkapnya Paijan, ayah Las. Paijan yang merupakan aktivis BTI diburu dan ditangkap oleh tentara pasca G30S atas informasi dari Pakde Suto. Paijan kemudian dieksekusi di jembatan Bacam, Solo. Jasadnya dihanyutkan ke sungai Bengawan Solo. Lihatlah kutipan berikut.

"Konon, Ayah digiring ke atas jembatan yang menghubungkan kedua tebing Bengawan Solo. Di bawah todongan pistol, Ayah diperintahkan bersujud, mata tertutup. Begitu dia dibentak supaya duduk kembali, dan manakala dadanya belum tegak benar, seorang pemuda melayangkan sebilah parang panjang ke tengkuknya, dan kepala Ayah, (Oh, Tuhan... aku takkan bisa memberikan ampun kepada mereka yang terlibat dalam pembantaian tiada tara dosanya itu!) kepala Ayah terpelanting ke bawah, dan dengan cepat tubuhnya ditendang menyusul kepalanya yang lebih dulu mencebur.... Ah, pantaskah sebuah peradaban memberikan ajal serupa itu kepada Ayah kami?!" (Aleida, 2009:94-95).

Peristiwa pembunuhan yang diangkat dalam cerpen-cerpen di atas dilakukan oleh tentara dan para tuan tanah yang tanahnya direbut secara paksa oleh para petani aktivis BTI. Korban pembunuhan adalah para petani dan pembela BTI. Mereka tak berdaya semenjak tentara dan masyarakat antikomunis mengejarngejar dan kemudian membunuh mereka secara kejam. 


\section{Penyiksaan}

Pelanggaran HAM berat berupa penyiksaan terdapat dalam kumcer MBBK, yaitu dalam cerpen Tanpa Pelayat dan Mawar Duka, Bertungkus Lumus, dan Dendang Perempuan Pendendam. Dalam cerpen yang pertama, penyiksaan dialami oleh tokoh sastrawan Bali, anggota Lekra. Sastrawan Bali tersebut diinterogasi dan disiksa oleh $\mathrm{Ba}$, seorang tentara. Lihatlah kutipan berikut.

"Tetapi, ketika dia mendengar seorang putra Bali, sastrawan yang pernah bergabung dalam Lekra, berangkat ke Jerman untuk menemui bekas pacarnya di sana, terbukalah celah buatnya untuk menjilat ke atas. Anak Bali itu, yang pernah mendekam hampir sepuluh tahun dalam tahanan, dia interogasi. Dia dituduh membangun jaringan baru di Eropa. Putra dari Bali itu menampik tuduhan, dan memilih untuk membiarkan sekujur tubuhnya dibalut balur-balur darah jejak sabetan ekor pari kering" (Aleida, 2009:25).

"Sastrawan Bali" dalam cerpen ini oleh penulis diidentifikasi sebagai Putu Oka Sukanta. Sastrawan ini memang pernah pergi ke luar negeri ketika G30S dan setelah pulang ke Indonesia kemudian ditangkap dan dihukum penjara selama sepuluh tahun sebagai tapol. Kini ia aktif di Lembaga Kreatifitas Kemanusiaan yang mengurusi advokasi korban 1965.

Dalam cerpen Bertungkus Lumus, unsur penyiksaan dialami tokoh "perempuan kita". Tokoh ini merupakan guru bahasa Inggris yang bersuamikan aktivis PKI. Setelah meletus G30S, suaminya menghilang. Ia sebagai istri disandera dan ditangkap dan dipaksa mengaku tentang keberadaan suaminya. Tokoh "perempuan kita" ini kemudian ditahan dan mengalami penyiksaan bahkan pemerkosaan. Lihatlah kutipan berikut yang menggambarkan nestapa yang dialami "perempuan kita" selama di tahanan.

"Bagaikan pelacur gudikan tak tahu malu dan tak laku, bokongnya ditendang sepatu larsa, dan dia dijorokkan bagai sampah ke dalam kamp konsentrasi-pusat penahanan yang tiba-tiba menjamur di kotanya menyusul peristiwa berdarah di Jakarta. Ditanya dengan membentak, di mana suaminya, dia menjawab tak tahu. Guru, mengapa berbohong?! pekik tentara memaksa. "Saya memang tak tahu, Pak. Kami menikah baru beberapa bulan, mengapa saya harus berbohong," jawabnya, membuat berahi si tentara terbakar. Kejujuran yang dititahkan kepada setiap guru yang baik, selalu menjadi pelita hatinya. Tetapi, di depan interogator yang haus darah, juga nyawa, pengakuan apa adanya hanya memancing bencana. Dia disiksa, diperkosa, untuk memperoleh pengakuan yang, demi Tuhan, memang mustahil" (Aleida, 2009:82).

Unsur penyiksaan ditampilkan lagi dalam cerpen Dendang Perempuan Pendendam. Dalam cerpen ini penyiksaan dialami tokoh Paklik Samin. Paklik Samin dituduh ikut menyembunyikan Paijan, aktivis BTI yang sedang diburu oleh tentara. Paklik Samin dipaksa mengaku untuk memberitahu keberadaan Paijan. Akhirnya, setelah disiksa, Paklik Samin memberitahukan keberadaan Paijan. Simaklah kutipan berikut.

"Suatu malam, Ayah menginap di rumah Paklik Samin. Paginya, setelah Ayah berangkat entah ke mana, Pakde Suto mendatangi rumah adiknya itu dan mengancam, "Kalau kowé lain kali berani menyimpan Paijan, kowé akan kubunuh!" Entah bagaimana, siangnya, tentara menggedor rumah Paklik Samin, dan dia digelandang ke dalam jip. Kabarnya, di markas tentara dia disiksa hingga beberapa kali tak sadarkan diri. Dia hanya selamat dari maut setelah menceritakan bahwa dari rumahnya Ayah berangkat ke Semarang, berjualan kacang tanah di salah satu pasar di kota itu" (Aleida, 2009:93). 
Tindakan penyiksaan dalam cerpen-cerpen di atas dilakukan oleh oknum tentara yang kepada tahanan atau orang yang dituduh terlibat dengan PKI. Oknum tentara ini digambarkan punya keleluasaan berlebih dalam menangani tahanan. Interogasi yang dilakukan disertai dengan unsur penyiksaan yang membuat tahanan menderita secara fisik maupun mental.

\section{Perkosaan dan Perbudakan Seksual}

Unsur pelanggaran HAM berat berupa perkosaan dan perbudakan seksual terdapat dalam kumcer MBBK yaitu di cerpen Leontin Dewangga dan Bertungkus Lumus. Dalam cerpen Leontin Dewangga, tokoh Dewangga yang anak seorang aktivis BTI, ikut terseret prahara yang menimpa ayahnya. Tahun 1965, Ayah Dewangga diambil algojo dan tak pernah kembali, sedangkan Dewangga dan ibunya ditahan dan kemudian dibebaskan setelah ditebus dengan keperawannya yang direnggut seorang komandan kamp. Simaklah kutipan berikut, tatkala Dewangga menceritakan kisah kelamnya kepada suaminya, Abdullah.

"Kurasakan jari-jari ayah yang ria dan penuh kasih sayang mengancingkan kalung berleontin mata uang perak itu di leherku ketika Ewa berusia tujuh belas. Ayah tak pernah pulang lagi, ketika tahun 1965 seorang algojo yang dikirim benggolan tuan-tanah datang untuk merenggutnya dari kami. kemudian ibu dan aku juga ditahan. Dan kemerdekaanku tertebus setelah komandan kamp meniduriku dengan paksa" (Aleida, 2009: 66).

Nasib serupa dialami tokoh "perempuan kita" dalam cerpen Bertungkus Lumus. Tokoh "perempuan kita" ditangkap dan ditahan oleh tentara karena dianggap menyembunyikan keberadaan suaminya yang aktivis PKI. Ia bahkan disiksa dan diperkosa oleh tentara yang memaksa pengakuannya. Lihatlah kutipan berikut yang menggambarkan penistaan oleh tentara terhadap tokoh "perempuan kita".

"Bagaikan pelacur gudikan tak tahu malu dan tak laku, bokongnya ditendang sepatu larsa, dan dia dijorokkan bagai sampah ke dalam kamp konsentrasi-pusat penahanan yang tiba-tiba menjamur di kotanya menyusul peristiwa berdarah di Jakarta. Ditanya dengan membentak, di mana suaminya, dia menjawab tak tahu. Guru, mengapa berbohong?! pekik tentara memaksa. "Saya memang tak tahu, Pak. Kami menikah baru beberapa bulan, mengapa saya harus berbohong," jawabnya, membuat berahi si tentara terbakar. Kejujuran yang dititahkan kepada setiap guru yang baik, selalu menjadi pelita hatinya. Tetapi, di depan interogator yang haus darah, juga nyawa, pengakuan apa adanya hanya memancing bencana. Dia disiksa, diperkosa, untuk memperoleh pengakuan yang, demi Tuhan, memang mustahil" (Aleida, 2009:82).

Nasib malang tak berhenti merundung, "perempuan kita" kemudian dibebaskan dari tahanan oleh seorang kapten untuk dibawanya ke rumah kontrakannya. Di rumah ini, "perempuan kita" diperbudak lahir batin dan kemudian dicampakkan begitu saja setelah melahirkan seorang anak laki-laki akibat hubungannya dengan sang kapten. Dengan susah payah, ia bekerja sebagai guru les bahasa Inggris demi membesarkan anak semata wayangnya tersebut. Lihatlah kutipan berikut.

"Hari-hari dilalui perempuan kita itu tak lebih dari sekadar seorang budak gratisan, malammalam dia lewati tak lebih dari sekadar segumpal daging simpanan. Ketika dia sudah hamil dan melahirkan anak laki-laki, kapten itu mengabarkan dia dipindahkan ke pulau seberang, dan akan kembali menjemputnya. Kata-kata itu cuma janji yang cuma menjadi cobaan hidup yang baru buat perempuan kita itu " (Aleida, 2009:83). 
Perkosaan dan perbudakan seksual dalam kedua cerpen di atas dialami oleh para korban yang tidak terlibat secara langsung dengan PKI. Status mereka sebagai perempuan dilecehkan sedemikian rupa oleh oknum tentara yang tidak bertanggungjawab.

\section{Penghilangan Orang Secara Paksa}

Pelanggaran HAM berat berupa penghilangan orang secara paksa ditampilkan dalam dua cerpen yakni Leontin Dewangga dan Ode untuk Selembar KTP. Dalam cerpen Leontin Dewangga, ayah Dewangga yang seorang aktivis BTI, ditangkap oleh benggolan-benggolan tuan tanah. Semenjak itu, ayah Dewangga tak pernah kembali dan keberadaannya pun tak diketahui. Lihatlah kutipan berikut yang menggambarkan petaka yang merundung keluarga Dewangga.

"Kurasakan jari-jari ayah yang ria dan penuh kasih sayang mengancingkan kalung berleontin mata uang perak itu di leherku ketika Ewa berusia tujuh belas. Ayah tak pernah pulang lagi, ketika tahun 1965 seorang algojo yang dikirim benggolan tuan-tanah datang untuk merenggutnya dari kami. kemudian ibu dan aku juga ditahan. Dan kemerdekaanku tertebus setelah komandan kamp meniduriku dengan paksa" (Aleida, 2009: 66).

Pada cerpen Ode untuk Sebuah KTP, penghilangan orang secara paksa dialami oleh suami Iramani yang seorang redaktur harian yang berafiliasi kiri. Suami Iramani tak diketahui keberadaan dan nasibnya pasca Tragedi 1965. Lihatlah kutipan berikut.

"Aku tak tahu kesalahan apa kesalahan yang dilakukan suamiku menjelang tahun 1965, sehingga dia harus dilenyapkan. Dan istrinya, anak-anaknya yang masih merah, harus menderita" (Aleida, 2009:72).

Penghilangan orang secara paksa merupakan kasus yang dialami oleh orangorang PKI pasca 1965. Tercatat tokoh PKI seperti Njoto dan DN Aidit mengalami kejadian ini. Nyoto diculik oleh sekelompok orang pada pada tahun 1966 dan nasibnya tak pernah diketahui hingga kini. DN Aidit juga mengalami hal serupa. Dia dilenyapkan setelah tertangkap oleh aparat yang mengejarnya pasca G30S.

\section{Pemusnahan}

Unsur pemusnahan sebagai bentuk pelanggaran HAM berat terdapat dalam cerpen Leontin Dewangga. Dikisahkan tokoh Abdullah Peureulak dipenjara karena menjadi anggota serikat buruh film yang berafiliasi dengan PKI. Cuma setahun Abdullah dipenjara. Dia dibebaskan karena petugas mendapatkan sepucuk surat dari orang tua Abdullah yang mengabarkan keberangkatan haji mereka. Abdullah dianggap anak seorang muslim taat yang tak pantas dipenjara lebih lama.

Abdullah dibebaskan dengan perasaan tidak tenang. Dia merasa sakit hati karena temen-temannya masih banyak mendekam dipenjara. Dan kebanyakan mereka dalam kondisi sakit akibat siksaan dan penyakit. Para petugas melakukan pembiaran dengan tidak menyuplai obat-obatan bagi yang sakit, sehingga belasan orang tahanan meninggal akibat kolera. Lihatlah kutipan berikut yang menggambarkan perasaan Abdullah ketika meninggalkan penjara. 


\begin{abstract}
"Sakit hatinya mengingat teman-teman yang masih mendekam di tahanan. Sementara dia dilepas melenggang bebas. Di antara yang dia tinggalkan banyak yang harus bertahan terhadap berbagai siksaan dan penyakit. Dua hari yang lalu misalnya, dia dengar kabar belasan tahanan mati karena kolera di penjara Tangerang. Dan wabah masih berkecamuk. Mereka yang berkuasa atas nyawa manusia di penjara itu tidak peduli. Konon pula menyediakan obat-obatan. Keluarga tahanan sendirilah yang harus menyelamatkan jiwa mereka yang dikucilkan dijepit tembok, apakah itu bernama suami, istri, anak atau kerabat mereka, dengan jalan menyelundupkan obatobatan" (Aleida, 2009:55-56).
\end{abstract}

\title{
6. Diskriminasi
}

Unsur diskriminasi diangkat pengarang dalam cerpen Ode untuk Selembar KTP. Cerpen ini mengangkat kisah Iramani, seorang perempuan tua berusia 72 tahun yang selalu merasa gelisah dan tersiksa dengan simbol ET yang tercantum dalam KTPnya. Iramani adalah mantan tapol. Ia pernah dipenjara selama tiga belas tahun di berbagai penjara, cuma karena ia adalah istri seorang redaktur harian yang dianggap berafiliasi dengan PKI.

Setelah bebas dari tahanan, penderitaan Iramani tak serta merta sirna. Diskriminasi dialaminya melalui dua huruf (berupa ET: Eks Tapol) yang tercantum dalam tanda pengenal KTPnya. Dua huruf yang menyengsarakannya, dan membuat keluarganya ikut menanggung stigma buruk dari masyarakat. Lihatlah dua kutipan berikut.

"Memang, ada yang mengatakan kartu ini adalah salah satu bentuk pelanggaran terhadap hak-hak mendasar manusia. Hak bergerak bebas. Karena KTP merupakan perangkat kekuasaan untuk mengamati gerak-gerik warganya. Orang jadi tak bisa bebas bergerak tanpa ada mata yang mengawasinya. Sama dengan sapi yang harus membawa cacat yang ditinggalkan besi merah yang ditancapkan di punggungnya ke manapun dia merumput dan memamah-biak. Tapi, aku tidak termasuk yang hanyut dalam sikap seperti itu. Karena aku memang seorang wanita yang terbuang bersama ribuan orang lain yang senasib. Kalau KTP ini dianggap sebagai kebejatan penguasa, apalagi yang akan dikatakan begitu melihat simbol yang diterakan di pojok kartu ini? Tiga huruf yang menyengsarakan, mematikan..." (Aleida, 2009: 71-72).

"Aku tidak sendiri menjalani nasib seperti ini. Dan tak bisa kau bayangkan betapa tertekannya perasaan dipencilkan seperti itu. Bukan aku saja yang harus melata karena cap itu. Juga anak-anakku. Pintu tertutup buat kami untuk memasuki kehidupan yang normal. Kami semua benar-benar menjadi paria karena cap yang melekat di pojok tanda pengenal itu. Lebih dari duapuluh tahun aku mengantungi hukuman itu. Hanya karena aku seorang istri” (Aleida, 2009:72).

Meski keputusan penghapusan tanda ET dalam KTP sudah ditetapkan pemerintah, Iramani tak mau menunggu lebih lama lagi, hingga ia bertekad untuk menghapuskannya lebih cepat walau dengan cara menyuap petugas kelurahan. Bahkan untuk memuluskan rencananya tersebut, Iramani sampai menjual sebidang tanahnya di Solo. Perbuatan yang disayangkan dan dianggap bodoh anak bungsunya, Tatiana.

Bagi Iramani, terlepas dari belenggu diskriminasi dalam simbol dua huruf dalam KTPnya merupakan wujud kebebasan yang diidamkannya. Kegembiraan tak terbendung seperti dalam kutipan berikut.

"Kemarin, ketika aku pulang dari kantor kelurahan, mengambil kartu tanda pendudukku, sudah kupuaskan sepuas-puasnya mata dan hatiku dengan KTP yang baru ini. Rasanya, keterangan diri yang mungil, dan dibalut plastik mengkilap itu, telah memberikan kegembiraan yang jauh lebih besar dibandingkan dengan hari ketika aku digelandang keluar dari Pelatungan, lebih dua puluh tahun yang lampau" (Aleida, 2009:71). 
Dalam cerpen ini, pengarang dengan sengaja memilih nama tokoh utamanya yaitu Iramani. Iramani merupakan nama lain dari seorang petinggi PKI yang juga merupakan editor Harian Rakyat, yaitu Nyoto. Tokoh ini sangat dikagumi pengarang hingga ia dedikasikan cerpen ini kepada istri Nyoto atas ketabahan menanggung penderitaan (Aleida, 2003:xvi).

Pencantuman tanda ET pada KTP merupakan bentuk diskriminasi oleh negara sebagai manifestasi wacana "bahaya laten komunisme" yang digulirkan. Peraturan ini diwujudkan melalui Peraturan Menteri Dalam Negeri No 32/1981 yang secara jelas memberikan batasan-batasan ketat terhadap Eks Tapol G30S, antara lain: 1) keharusan mencantumkan kode ET (Eks Tapol) pada KTP. Pencantuman ini menyebabkan dihambatnya yang bersangkutan mencari pekerjaan dan semua pasar kerja akan takut menerimanya; (2) melakukan pembatasan pekerjaan bagi mereka untuk menjadi dosen/guru, wartawan, lembaga bantuan hukum, pendeta, dan sebagainya yang tidak diperinci sehingga sangat elastis; (3) mencegah mereka memasuki kegiatan kemasyarakatan yang dianggap mungkin menimbulkan kerawanan di bidang sosial politik, sosial ekonomi, sosial budaya, dan keamanan-ketertiban-nasional; (4) untuk bepergian dalam negeri meninggalkan kelurahan/desa tempat domisili lebih dari 7 hari, harus dengan izin khusus. Warga negara biasa tidak memerlukan izin tersebut; (5) untuk berpergian ke luar negeri atau melakukan ibadah haji, harus mempunyai konduite baik dan ada jaminan tertulis dari seseorang/instansi yang dapat dipertanggungjawabkan bahwa yang bersangkutan akan kembali ke daerah domisili semula, serta telah mendapat santiaji dari pejabat atau petugas setempat (Narwaya, 2010:116-117). Aturan ini kemudian dihapuskan pada masa pemerintahan Abdurrahman Wahid (Gus Dur) melalui pembubaran Bakorstanas (Badan Koordinasi Bantuan Pemantapan Stabilitas Nasional), lembaga yang mengurusi "litsus" (penelitian khusus) di pusat dan daerah. Mengenai keputusan Gus Dur ini disinggung dalam cerpen ini. Lihatlah kutipannya berikut.

"Ibu menghabiskan jutaan rupiah untuk ini?! Perbuatan sia-sia...!"Aku tahu dia menahan amarah ketika mengatakan bahwa sogok-menyogok sudah bukan menjadi milik zaman anak-anak muda sekarang ini. Dan tanda penderita lepra yang berlambang ETP itu sudah dihapuskan pemerintah. Gong sudah ditalu. Siksa itu harus diakhiri. Karena Presiden Republik yang sekarang ini, ketika dia masih seorang kiai yang buta dengan hati yang baik setinggi langit, telah diterangi Tuhan pikirannya untuk meminta maaf atas kejahatan yang dilakukan terhadap orang-orang seperti aku ini” (Aleida, 2009:75-76).

Hersri Setiawan dalam bukunya Kamus Gestok (2003:77) menjelaskan bahwa Eks Tapol (ET) merupakan tanda selar atau stigma berupa dua huruf singkatan yang dituliskan sebagai ET, tanpa titik; dibubuhkan pada KTP para bekas tapol G30S. Tanda ET ini kemudian muncul variannya yaitu O.T., kependekan dari Organisasi Terlarang. Stigma ini dibubuhkan pada seseorang bukan eks tapol G30S, tapi kepada mereka yang digolongkan anggota organisasiorganisasi terlarang sebagai yang dianggap "ekstrem kiri" atau "ekstrem kanan", atau mereka yang dianggap tidak "bersih lingkungan".

Dalam cerpen-cerpen MBBK, tercatat enam pelanggaran HAM yang ditampilkan/diangkat oleh pengarang. Dari keenam pelanggaran HAM tersebut, lima di antaranya adalah termasuk pelanggaran HAM berat yang tergolong 
kejahatan kemanusiaan, yaitu pembunuhan, penyiksaan, perkosaan dan perbudakan seksual, penghilangan orang secara paksa, dan pemusnahan, sedangkan satu lagi merupakan pelanggaran HAM biasa yaitu diskriminasi pada KTP.

\section{PENUTUP}

Tekstualitas sejarah dalam kumcer MBBK memberikan perspektif berbeda tentang Tragedi 1965. Kalau selama ini perhatian tentang sejarah Tragedi 1965 berpusat pada pembicaraan tentang "siapa dalang tragedi G30S", maka dalam kumcer MBBK, perhatian yang diberikan lebih pada dampak sesudahnya, yakni adanya pelbagai pelanggaran HAM berat meliputi pembunuhan, penyiksaan, perkosaan dan perbudakan seksual, penghilangan orang secara paksa, pemusnahan, dan diskriminasi. Kumcer ini juga mengekplorasi dampak dari pelbagai pelanggaran HAM yang dialami korban tersebut berupa ekspresi dendam yang muncul di benak korban dengan pelbagai penyelesaiannya. Kumcer ini juga memberikan ironi kemanusiaan dan beberapa penyangkalan atas stereotipisasi yang melekat pada orang-orang PKI antara lain tentang sisi kemanusian yang melekat pada orang-orang yang dituduh PKI. Tidak benar bahwa semua orang PKI itu seperti iblis yang suka menculik dan membunuh. Tidak selalu benar juga bahwa semua orang muslim antipati dengan PKI, sehingga memunculkan jurang pemisah yang tak terjangkau. Orang-orang muslim (yang taat) juga berhubungan sosial secara wajar dengan orang-orang PKI.

Sejarah Tragedi 1965 yang diusung dalam kumcer MBBK adalah sejarah yang lebih peduli pada akibat daripada sebab, lebih peduli pada jejak suatu tindakan daripada tindakan itu sendiri, lebih peduli pada penggunaan dan penyalahgunaan suatu "kejadian" daripada "kejadiannya" itu sendiri. Implikasinya, kumcer ini memiliki peran dalam upaya mengubah persepsi dan kesadaran pembacanya tentang sejarah Tragedi 1965, bahwa di samping peristiwa pembunuhan para jenderal, sesungguhnya terjadi pula pelbagai kejahatan kemanusiaan yang dialami ratusan ribu orang yang dianggap PKI. Karya sastra ini juga turut menebarkan empati dan simpati pada sesuatu yang esensial, yakni kemanusiaan.

Fakta-fakta cerita yang ditampilkan dalam cerpen-cerpen ini memang bukan laporan penelitian pelanggaran HAM, bukan pula paper sejarah yang bersifat akademik, yang dapat diacukan sebagai bukti di pengadilan. Namun cerita-cerita yang diangkat merupakan kesaksian atas sejumlah kejadian yang pernah ada. Kebenaran yang diusung adalah kebenaran (yang menjunjung) kemanusiaan.

\section{DAFTAR PUSTAKA}

Abrams. M.H. (1999). A Glossary of Literary Terms (Seventh Edition). Boston: Heinle \& Heinle.

Aleida, Martin. (2009). Mati Baik-Baik, Kawan. Yogyakarta. Akar Indonesia. (2003). Leontin Dewangga. Jakarta: Penerbit Buku Kompas.

Barry, Peter. (2002). Beginning Theory: An Introduction to Literary and Cultural Theory. Manchester \& New York: Manchester University Press. 
Tuah Talino

Tahun XIII Volume 13 Nomor 1 Edisi 5 Juli 2019

ISSN 0216-079X

Balai Bahasa Kalimantan Barat

Budianta, Melani. (2006). Budaya, Sejarah, dan Pasar: New Historicism dalam Perkembangan Kritik Sastra (dalam Jurnal Susastra 3 tahun 2006). Jakarta: Yayasan Obor.

Cribb, Robert (Ed). (2012). Soal Statistik Korban (dalam Majalah Tempo, edisi 17 Oktober 2012).

Faruk. (1999). Pengantar Sosiologi Sastra. Yogyakarta: Pustaka Pelajar.

Gallagher, Catherine \& Stephen Greenblatt. (2000). Practicing New Historicism. Chicago: The University of Chicago Press

Greenblatt, Stephen. (1980). Renaissance Self-Fashioning: From More to Shakespeare. Chicago \& London: The University of Chicago Press.

Greenblatt, Stephen. (2005). The Greenblatt Reader. Victoria: Blackwell Publishing.

Montrose, Louis A. (1989). Professing the Renaissance: The Poetics and Politics of Culture dalam Aram H. Veeser, The New Historicism, London, New York: Routledge.

Narwaya, Tri Guntur. (2010). Kuasa Stigma dan Represi Ingatan. Yogyakarta: Resist Book.

Purwanto, Bambang. (2001). Historisisme Baru dan Kesadaran Dekonstruktif: Kajian Kritis terhadap Historiografi Indonesiasentris (dalam Jurnal Humaniora, Volume XIII No. 1/2001). Yogyakarta: Unit Pangkajian dan Publikasi Fakultas Ilmu Budaya Universitas Gadjah Mada.

Roosa, John. (2008). Dalih Pembunuhan Massal: Gerakan 30 September dan Kudeta Suharto. Jakarta: Institut Sejarah Sosial Indonesia dan Hasta Mitra.

Sulistyo. Hermawan. (2000). Palu Arit di Ladang Tebu: Sejarah Pembantaian Massal yang Terlupakan (Jombang-Kediri 1965-1966). Jakarta: Kepustakaan Populer Gramedia.

Veeser, Aram H (ed.). (1989). The New Historicism. London, New York: Routledge.

Wardaya, Baskara T. (2011). Suara di Balik Prahara; Berbagai Narasi Tentang Tragedi '65. Yogyakarta: Galang Press.

White, Hayden. (1989). New Historicism: A Comment dalam Aram H. Veeser, The New Historicism, London, New York: Routledge. 